\title{
Determinants of Production and Income Risks of Rainfed Lowland Farming: A Case Study in Maros Regency, Indonesia
}

\author{
Arifin $^{1 *}$, Muhammad Arsyad Biba ${ }^{1}$ and Syafiuddin ${ }^{2}$ \\ ${ }^{1}$ Department of Agribusiness, Faculty of Agriculture, Animal Husbandry and Forestry, \\ Muslim University of Maros, Indonesia; ${ }^{2}$ Department of Agribusiness, Faculty of Agriculture, \\ Muhammadiyah University of Makassar, Indonesia \\ ${ }^{*}$ Corresponding author: arifin.maros13@gmail.com
}

\begin{abstract}
Rainfed lowland farming production is generally lower than irrigated lowland rice due to area differentiation regional features. Rainfed lowland rice farming can only produce rice during the rainy season because lowland rice cannot be planted in the dry season. The purposes of this study are (1) to analyze the risk of production and income of rice farming in rainfed lowland farming and (2) to investigate the factors influencing the risk of rice farming in rainfed lowland farming. Data were collected from 100 respondents of rice farmers in four sub-districts in Maros Regency using the multi-stage cluster random sampling technique. The analysis of production and income risks were performed using multiple linear regression with the heteroscedastic method. The results have shown that rice farming in rainfed lowland farming poses a risk to production and income. The variables that significantly influence the rainfed lowland rice farming are land area, the number of seeds, the amount of urea fertilizer and the amount of pesticide. Farmers are required to manage risk by prioritizing the effectiveness and efficiency production factors as needed. Similarly the government is expected to assist farmers in maintaining the level of rice selling prices.
\end{abstract}

Keywords: income risk; production risk; rainfed lowland; rice farming

Cite this as: Arifin, Biba, M. A., \& Syafiuddin. (2021). Determinants of Production and Income Risks of Rainfed Lowland Farming: A Case Study in Maros Regency, Indonesia. Caraka Tani: Journal of Sustainable Agriculture, 36(2), 319-328. doi: http://dx.doi.org/10.20961/carakatani.v36i2.47713

\section{INTRODUCTION}

Agricultural business is always characterized by high yield variability or risk (Adeosun and Opata, 2016; Wadu et al., 2019). Agricultural commodities have fluctuating prices for agricultural commodities and a segmented agricultural market due to local supply and demand conditions. Farmers are influenced by controllable (internal) and uncontrollable (external) factors causing risks or uncertainties (Lucas and Pabuayon, 2011; Arifin et al., 2019). Farmers become vulnerable to poverty due to these risks and uncertainties (Saleem et al., 2013).
Because agriculture is strongly influenced by nature, namely weather, pests, temperature, drought and flooding, the risk of agricultural production is greater than the risk of nonagriculture (Edeh et al., 2011; Singh et al., 2017; Magfira et al., 2020; Islam et al., 2021) Human resources, production inputs and natural factors can contribute to production risks (Rondhi et al., 2020). Production fluctuations are caused by production risks in the agricultural sector (Nurbudiati and Wulandari, 2020). Production problems are related to the nature of farming, which always depends on nature supported by risk factors, causing a high chance of failure

\footnotetext{
* Received for publication January 17, 2021

Accepted after corrections June 22, 2021
} 
to produce and accumulating at the risk of low income received by farmers (Suharyanto et al., 2015). The risk can reduce production and farmers' income (Asbullah et al., 2017).

The increase in risk in agriculture can be seen with the in income fluctuation (Sulewski and Gajewska, 2014). The marketing activities of agricultural products can pose a pricerelated risk because the market price cannot be controlled by farmers. Price fluctuations are more common in agricultural products (Zakirin et al., 2013). Agricultural income issues depend on environmental problems, technological challenges, economics and structural changes in agricultural policies and institutions (Novickyte, 2018). Reducing income risks will improve farmer welfare, competitiveness and the ability to develop activities through innovation. Likewise, agricultural technological can have a positive effect on low-income farming communities.

Rainfed lowland rice farming is the second most productive farming practice, after irrigated rice field farming; however, the rainfed lowland rice productivity is still considered low (Kasno et al., 2016). Rainfed lowland rice farming production is generally lower than that of irrigated rice farming. The differences in the irrigated lowland rice and rainfed lowland rice production at national, provincial and local levels are due to farming area differentiation related to regional characteristics. Rainfed lowland rice farming can only produce rice during the rainy season (Reda et al., 2015). The arrival of the rainy season has a large effect on the activities of rainfed lowland rice farmers. Farmers can only grow rice in the fields during the rainy season. Meanwhile, the areas cannot be planted with rice during the dry season due to a lack of irrigation facilities and a decrease in river water discharge (Yartiwi et al., 2018). One of the activities that can be accomplished by adjusting the cropping pattern is planning of planting. A good cropping pattern will produce good production yields by maximizing the availability of water to meet the water needs of the cropping pattern (Dwiratna et al., 2016).

Rice production Maros Regency is 324,323.11 tons with a harvest area of 49,363 hectares and rice field productivity is 4.26 tons $\mathrm{ha}^{-1}$ (BPS-Maros Regency, 2019). Irrigated rice fields contributed $210,810.02$ tons $(65.4 \%)$ and rainfed lowland rice farming contributed 112,280.66 tons $(34.6 \%)$. Rainfed lowland rice farming production in Maros Regency contributed to rice production in South Sulawesi by $5.60 \%$ and rainfed lowland rice farming production $1.90 \%$ (BPS-Statistics Indonesia Sulawesi Selatan Province, 2019). Although the contribution of rainfed lowland rice farming production remains small in comparison with irrigation rice production, a role in rice production in Maros and South Sulawesi Regencies.

Rice productivity can be increased by using balanced fertilization and high-yielding rice varieties. Climate change causes problems in agriculture, especially in rainfed lowland rice farming, where the source of water for production is highly dependent on rainfall, which is difficult to predict, making good planning is difficult (Hayashi et al., 2018). The potential contribution of rainfed lowland to increase rice production must be supported through the development of water resources infrastructure (Sulaiman et al., 2019).

Increasing land productivity is one of the determinants of rice farming sustainability in rainfed lowlands (Roy and Chan, 2015). The factors that contribute to the level of land productivity include planting area, high-yielding varieties, use of fertilizers and labor (Fitri and Mardhiah, 2018). Water is also an important factor in the efforts to boost rice production. Intensive use of water can support increased production yields (Rahmadiah et al., 2020). Anticipation of risks is pursued through plant cultivation, as well as cultivation techniques and management of rice plant nutrients (Lailiyah et al., 2017).

Maros Regency, one of the districts in South Sulawesi, has extensive rainfed lowland rice farming that contributes significantly to rice production. Identification of the factors that affect the risk of production of rainfed lowland rice farming in Maros Regency has never been carried out. Previous research related to the risk of rainfed lowland rice farming production in Maros Regency was still limited in terms of the location sample used, which was only one sample of the village. The novelty is the risk variable used to investigate the production risk related to the research location in four subdistricts and four villages. To identify the factors influencing the farming risk in rainfed lowland rice in Maros Regency, Just and Pope approach 
was used. The purpose of this study was to analyze the risk of rainfed lowland rice farming production and investigate the factors that influence the risk of rainfed lowland rice farming.

\section{MATERIALS AND METHOD}

This research was conducted from September to November 2020 in four sub-districts, namely Lau (Soreang Village), Bontoa (Bontobahari Village), Marusu (Bonto Mate'ne Village) and Tompobulu (Tompobulu Village), in Maros Regency, South Sulawesi Province of Indonesia. The research locations with rainfed lowland rice fields in South Sulawesi were selected purposively. This study applied a quantitative approach with a survey method design. The primary and secondary data were collected with observation, recording and interviewing. The population in this study were 1,247 farmers who carried out rice farming on rainfed lowland rice fields at the research locations and 100 people were taken as respondents in four sub-districts using the multi-stage cluster random sampling technique. From each sub-district village was selected, namely in Lau (Soreang Village), in Bontoa (Bontobahari Village), in Marusu (Bonto Mate'ne Village) and Tompobulu (Tompobulu Village). Production and income risks were analyzed by determining the coefficient of variation. Production and income risks can be measured by the amount of variance and deviation standard (Mutisari and Meitasari, 2019). The mathematical coefficient of variation can be written as follows:

$$
\begin{aligned}
\mathrm{CV} & =\frac{\sigma}{\overline{\mathrm{X}}} \\
\sigma & =\sqrt{\frac{\sum \mathrm{x}^{2}}{\mathrm{n}}}
\end{aligned}
$$

$$
\mathrm{x}=\mathrm{X}-\overline{\mathrm{X}}
$$

The lower limit value of production and income was determined with the following formula:

Where:

$$
L=\overline{\mathrm{X}}-2 \sigma
$$

$\mathrm{CV}=$ coefficient of variation in production and income

$\sigma \quad=$ deviation standard of production and income (variant)

$\overline{\mathrm{X}}=$ average production and income

$\mathrm{n} \quad=$ number of samples

$\mathrm{L} \quad=$ lower limit of production and income

The decision was made by considering particular criteria (Asbullah et al., 2017):

1) The value of $\mathrm{CV} \leq 0.50$ or $\mathrm{L} \geq 0$ indicates that farmers avoid production and income risks in carrying out rice farming in rainfed lowland rice fields.

2) The value of $\mathrm{CV}>0.50$ or $\mathrm{L}<0$ indicates that farmers are at risk for production and income in carrying out rice farming in rainfed lowland rice fields.

A Just and Pope model approach and multiple linear regression analysis were utilized to determine the inputs on production risk. The function of production risk $\mathrm{h}(\mathrm{X}) \varepsilon$ was estimated by regressing $\sigma^{2} \mathrm{i}$ to variable $\mathrm{X}$. The next step was estimating the production function $f(X)$ and the risk function $h(X)$ together with the maximum likelihood approach by minimizing the number of squares of the two functions. The multiplicative heteroscedasticity model was applied by maximizing the likelihood function (Asmara et al., 2019; Chrisdiyanti and Yuliawati, 2019; Fadlilah et al., 2019). The regression models for the effects of the use of inputs on production and production risk were as the following.

Production function:

$$
\mathrm{Ln} Y=\ln \alpha_{0}+\alpha_{1} \ln \mathrm{X}_{1}+\alpha_{2} \ln \mathrm{X}_{2}+\alpha_{3} \ln \mathrm{X}_{3}+\alpha_{4} \ln \mathrm{X}_{4}+\alpha_{5} \ln \mathrm{X}_{5}+\varepsilon_{1}
$$

Production risk function:

Where:

$$
\operatorname{Ln} \varepsilon_{1}^{2}=\ln \beta_{0}+\beta_{1} \ln X_{1}+\beta_{2} \ln X_{2}+\beta_{3} \ln X_{3}+\beta_{4} \ln X_{4}+\beta_{5} \ln X_{5}+\varepsilon_{2}
$$

$\mathrm{Y}$

$\varepsilon_{1}{ }^{2}$

$\alpha_{0} ; \beta_{0}$

$\alpha_{1}-\alpha_{5} ; \beta_{1}-\beta_{5}$

$\varepsilon_{1} ; \varepsilon_{2}$

$$
\begin{aligned}
& =\text { rice production }(\mathrm{kg}) \\
& =\text { production risk (residual) } \\
& =\text { intercept } \\
& =\text { regression coefficient (estimated parameter) } \\
& =\text { error term (residual) }
\end{aligned}
$$




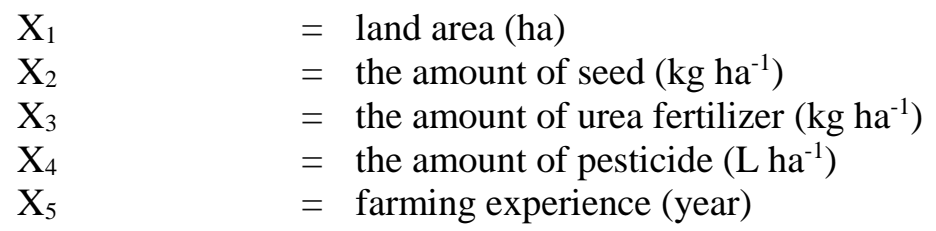

\section{RESULTS AND DISCUSSION}

\section{The Characteristics of respondents}

Farmer respondents have different characters and this condition influences making in running rainfed lowland rice farming. The characteristics of the respondents examined in this study include farmer's age, farmer education, cultivated land area and farming experience, which are presented in Table 1.

Table 1. Characteristics of respondents

\begin{tabular}{|c|c|c|c|}
\hline No. & Variables & Number of respondents (people) & Proportion $(\%)$ \\
\hline \multirow[t]{5}{*}{1.} & Farmer's age & & \\
\hline & $20-40$ years & 19 & 19 \\
\hline & $41-60$ years & 68 & 68 \\
\hline & $61-80$ years & 13 & 13 \\
\hline & Average (years) & 50.5 & \\
\hline \multirow[t]{5}{*}{2.} & Education level & & \\
\hline & Elementary school & 71 & 71 \\
\hline & Junior high school & 11 & 11 \\
\hline & Senior high school & 17 & 17 \\
\hline & Bachelor & 1 & 1 \\
\hline \multirow[t]{6}{*}{3.} & Land size of farm & & \\
\hline & $0.10-0.50$ (ha) & 62 & 62 \\
\hline & $0.51-1.00$ (ha) & 24 & 25 \\
\hline & $1.10-1.50$ (ha) & 13 & 13 \\
\hline & $1.51-3.00$ (ha) & 1 & 1 \\
\hline & Average (ha) & 0.32 & \\
\hline & Farming experience period & & \\
\hline & $\leq 10$ years & 9 & 9 \\
\hline & $10-25$ years & 23 & 23 \\
\hline & 25 years or above & 68 & 68 \\
\hline & Average (years) & 19.9 & \\
\hline
\end{tabular}

Based on age groups, rice farmers are dominated by productive age (Table 1). The productive age group can influence the success in managing and running the farm, especially in influencing the farmer's way of thinking and physical (Kurniati, 2014). Age greatly affects farmers' farming activities. Productive age is closely related to physical and decision-making abilities (Ibrahim et al., 2020). The husband, as the head of the household, serves as the main role and actor in farming activities.

The farmer's formal education level is classified as low. Formal education is an indicator of the quality of the workforce and the level of education generally affects people's way of thinking (Lailiyah et al., 2017). One measurement to support the optimal achievement of farmer work is the influence of the level of education and experience in participating in nonformal education, such as counseling and training. The higher the education level of farmers, the easier they are to receive and comprehend information, whether from newspapers, books, or extension officers (Safitri et al., 2020).

The most dominant size of arable land ranges from 0.10 to 0.50 ha, which is considered narrow, due to farmers' lack of capital to rent or purchase rice fields. Capital is highly important to obtain the whole or a part of livelihood, which is aimed at the activities in the agricultural sector (Magfiroh and Sofia, 2020). The farmers' 
narrowest area of arable land 0.10 ha, while the widest is 2.00 ha. Many farmers cultivate their land but some others do not have any land and therefore, they cultivate other people's land by practicing a profit-sharing system. In the profit-sharing system, the harvest yields are shared between the landowner and smallholder equally.

Most of the farmers experienced in farming for 25 years and above. The rest have practiced farming activities for 10-25 years and 10 years, respectively. These data have proven that the farmers are experienced and have inherited the farming activities and business from their parents, through non-formal education, such as training and counseling from agricultural extension officers. In general, farmers with much experience in farming have better knowledge and skills in farming practices. Likewise, based on this experience, farmers can develop their farming (Mastrordianto et al., 2019).

\section{Production risks and income of rice farming in rainfed lowland rice fields}

Production and income risk can trigger fluctuations in production and income in business and therefore, it is necessary to calculate the amount of production risk and income to determine the most appropriate actions to overcome those challenges. The production and income risks of rice farming in rainfed lowland rice fields in Maros Regency can be seen from the coefficient of variation (Table 2).

Table 2. Production and income risks of rice farming in rainfed lowland rice fields in Maros Regency

\begin{tabular}{lcr}
\hline \multicolumn{1}{c}{ Description } & Production $(\mathrm{kg})$ & \multicolumn{1}{c}{ Income (IDR) } \\
\hline Average $(\overline{\mathrm{X}})$ & $1,242.35$ & $4,532,981.20$ \\
Lower limit $(\mathrm{L})$ & -702.15 & $-3,409,593.84$ \\
Standard deviation $(\sigma)$ & 972.25 & $3,971,287.52$ \\
Variant & $945,272.73$ & 0.88 \\
Coefficient of variation $(\mathrm{CV} \%)$ & 0.78 & $15,771,124,573,070.60$ \\
\hline
\end{tabular}

The results of the lower limit (L) and the coefficient of variation $(\mathrm{CV})$ of production and income are presented in Table 2. The value of the lower limit of production and income is negative, which is smaller than zero $(\mathrm{L}<0)$, signifying that rice farming in rainfed lowland rice fields is at risk of production and income. Based on the decision making criteria, including the lower limit value and the coefficient of variation, farmers are at risk to production and income in carrying out rice farming in rainfed lowland rice fields.

However, the coefficient of variation is greater than $0.5(\mathrm{CV}>0.5)$, exemplifying that rice farming in rainfed lowland rice fields is also at risk of production and income. The coefficient of variation in production is 0.78 , which means that the opportunity for reduced production is $78 \%$ and the possibility to achieve stable production is very low. Meanwhile, the coefficient of variation in income is 0.88 , which denotes that the opportunity to reduce income is $88 \%$ and the possibility to obtain stable income is very low. The coefficient of variation in production and income that is greater than $0.5(\mathrm{CV}>0.5)$ indicates that the production and income of rice farming in rainfed lowland rice fields are at risk, based on the decision making.

Production and income risks experienced by the farmers in the research locations are due to the weather or erratic rainfall intensity and an increase in snail and rat populations attacking rice plants, which is the main cause of lack of production and crop failure. Data reported that a total of $2.11 \%$ hectares of rice fields were affected by flooding and $0.57 \%$ hectares of the areas experienced crop failure, while $0.46 \%$ hectares were attacked by pests and $0.05 \%$ hectares were struck by snails (BPSMaros Regency, 2019; BPS-Statistics Indonesia Sulawesi Selatan Province, 2019). The decrease in production contributes to a decrease in farmers' income and an increase in income risk. The findings are in line with the report of previous study Mardliyah and Mirayana (2019) that the decline in production due to pests, plant diseases and weather occurring with excessive rainfall causes fluctuations in production and therefore, farmers must bear a large income risk. Plant pests, particularly rats and snails, attacking rice plants pose a threat to the majority of farmers. 
Factors affecting the risk of rice farming in rainfed lowland rice fields

The factors contributing to the production of rice farming in rainfed lowland rice fields are demonstrated in Table 3. Variations in the independent variables, which include land area, the number of seeds, the amount of urea fertilizer, the amount of pesticide and farming experience, can explain $99 \%$ of the variation in rainfed lowland rice field production (Table 3 ). The independent variables of land area and farming experience have no significant effect on the production of rainfed lowland rice fields. The increase in land area does not result in a growth in rice production because rainfed lowland rice fields are limited in planting intensity, planting rice is only done once a year and production remains low. Rainfed rice fields can only be planted and produce rice during the rainy season (Yartiwi et al., 2018). Farming experience does not affect increasing rice production in rainfed lowland rice fields, this is related to the level of education of farmers. In general, the education level of farmers is low, dominated by primary school graduates, affecting the technology transfer in agriculture. Support for technology transfer relies on not only farming experience but also education level. Educated farmers understand the use of technology more easily and are more willing to accept innovations (Murdayanti et al., 2021). The coefficient for the number of seeds, the amount of urea fertilizer and the amount of pesticide are all positive, indicating that each additional production factor will increase the production of rainfed lowland rice fields.

Table 3. Factors affecting the production of rice farming in rainfed lowland rice fields

\begin{tabular}{lcc}
\multicolumn{1}{c}{ Variables } & Regression coefficient & Standard error \\
\hline Constant $(\mathrm{C})$ & $6.231^{* * *}$ & 0.929 \\
Land area $\left(\mathrm{X}_{1}\right)$ & -0.167 & 0.118 \\
Seeds $\left(\mathrm{X}_{2}\right)$ & $0.217^{* *}$ & 0.108 \\
Nitrogen fertilizer $\left(\mathrm{X}_{3)}\right.$ & $0.283^{* * *}$ & 0.037 \\
Pesticides $\left(\mathrm{X}_{4}\right)$ & $0.562^{* * *}$ & 0.087 \\
Farming experience $\left(\mathrm{X}_{5}\right)$ & -0.067 & 0.068 \\
\hline $\mathrm{R}^{2}$ & & 0.990 \\
$\mathrm{R}$-squared & & 0.980 \\
F-statistics & & $899.269^{* * *}$ \\
\hline
\end{tabular}

Note: $* * *=$ significant at $1 \% ; * *=$ significant at $5 \%$

Furthermore, the factors affecting the risk of rainfed lowland rice field production were estimated using the Least Square Method, with the risk of rainfed lowland rice field production (residual) serving as the dependent variable. The results of the analysis are presented in Table 4.

Table 4. Factors affecting the risk of rice farming in rainfed rice fields

\begin{tabular}{lcc}
\hline \multicolumn{1}{c}{ Variables } & Regression coefficient & Standard error \\
\hline Constant $(\mathrm{C})$ & $43.401^{* * *}$ & 6.080 \\
Land area $\left(\mathrm{X}_{1}\right)$ & $-1.301^{* *}$ & 0.566 \\
Seeds $\left(\mathrm{X}_{2}\right)$ & $-2.644^{* * *}$ & 0.606 \\
Nitrogen fertilizer $\left(\mathrm{X}_{3)}\right.$ & $-0.441^{*}$ & 0.232 \\
Pesticides $\left(\mathrm{X}_{4}\right)$ & $-1.677^{* *}$ & 0.508 \\
Farming experience $\left(\mathrm{X}_{5}\right)$ & 0.113 & 0.326 \\
\hline $\mathrm{R}^{2}$ & & 0.941 \\
$\mathrm{R}$-squared & & 0.886 \\
F-statistics & & $146.131^{* * *}$ \\
\hline
\end{tabular}

Note: $* * *=$ significant at $1 \% ; * *=$ significant at $5 \% ; *=$ significant at $10 \%$

In general, the farmers in the research area grow rice using direct seeding, which uses more seeds than growing with transplanting. The farmers use direct seeding tools they design but the tools have a particular drawback, causing them to use more seeds. To save water and labor, the traditional farming practices with puddle transplantation can be replaced zero-till direct- 
seeded rice (Kumar et al., 2015). The use of quality seed is one of the efforts to reduce the production risk in rainfed rice fields. This is consistent with the outcome of the previous study that increasing the use of quality seeds will, to a certain extent, increase the plant population, thereby increasing productivity and ultimately, reducing the production risk (Zakirin et al., 2013).

Farmers in the research area use nitrogen fertilizer, but not in the amount that is required. By increasing the use of nitrogen fertilizer within a certain limit, the production of rainfed lowland rice fields can be increased while the risk of production can be lowered. Zakirin et al. (2013) suggest that production will increase with the addition of nitrogen fertilizer to the recommended dosage.

These findings indicate that pesticide use has not reached the maximum usage requirement, implying that by increasing the amount of pesticide to combat pests and diseases in rice, production can be increased while the risk of production can be reduced. Suharyanto et al. (2015) and Lailiyah et al. (2017) advocate that rice farmers use pesticides as a preventive measure and in proportion to the level of pest attack. The control more directed at both anticipating and dealing with the risk of plant pest attack. If pests and diseases become more prevalent, appropriate pesticides are given in greater quantity to them (Mita et al., 2020).

\section{CONCLUSIONS}

Rice farming in rainfed lowland rice farming in Maros Regency is at risk of production and income. Factors that significantly influence the risk of farming are land area, the number of seeds, the amount of nitrogen fertilizer and the amount of pesticide. Farmers are required to manage the risk by prioritizing the effectiveness and efficiency with they use production factors as needed. Likewise, the government is expected to assist farmers in maintaining the level of rice selling prices.

\section{ACKNOWLEDGEMENT}

The authors are grateful to the Government of Maros Regency, through the Agricultural Extension Service, for the material and nonmaterial support in completing this research.

\section{REFERENCES}

Adeosun, K. P., \& Opata, P. I. (2016). Unravelling risk structures in nigeria's rice supply chain: a review of the literature. European Journal of Business and Management, 8(6), 26-34. Retrieved from https://iiste.org/Journals/index .php/EJBM/article/view/29054

Arifin, Zulkifli, Biba, M. A., Pata, A. A., \& Sadat, M. A. (2019). Risiko Produksi dan Efisiensi Teknis Usahatani Padi pada Sawah Tadah Hujan di Kabupaten Maros, Sulawesi Selatan. Jurnal Agrisep, 18(2), 403-411. Retrieved from https://www.researchgate.net/publicatio n/336456624_Production_Risk_and_Technic al_Effisiency_of_Rice_Farming_in_Rainfed_ Rice_Fields_in_Maros_Regency_South_Sula wesi/fulltext/5da12c5aa6fdcc8fc3491e7e/Pro duction-Risk-and-Technical-Effisiency-of-Ric e-Farming-in-Rainfed-Rice-Fields-in-MarosRegency-South-Sulawesi.pdf

Asbullah, M., Hapsari, T. D., \& Sudarko. (2017). Analisis risiko pendapatan pada usahatani padi organik di Desa Lombok Kulon Kecamatan Wonosari Kabupaten Bondowoso. Jurnal Sosial Ekonomi Pertanian, 10(2), 35-42. https://doi.org/10.19184/jsep.v10i2.4552

Asmara, R., Widyawati, W., \& Hidayat, A. H. (2019). Preferensi resiko petani dalam alokasi input usahatani jagung menggunakan model just and pope. Jurnal Ekonomi Pertanian dan Agribisnis, 3(2), 449-459. https://doi.org/ 10.21776/ub.jepa.2019.003.02.20

BPS-Statistics Indonesia Sulawesi Selatan Province. (2019). Sulawesi Selatan Province in Figures 2019. Retrieved from https:// sulsel.bps.go.id/publication/2019/08/16/990ca ae $13 \mathrm{~d} 6 \mathrm{f} 4 \mathrm{c} 5 \mathrm{~d} 743 \mathrm{e} 852 \mathrm{~b} /$ provinsi-sulawesi-sela tan-dalam-angka-2019.html

BPS-Maros Regency. (2019). Maros Regency in Figures 2019. Retrieved from https:// maroskab.bps.go.id/publication/2019/08/16/2 9239258c554034ae6c0fc79/kabupaten-marosdalam-angka-2019.html

Chrisdiyanti, Y. K., \& Yuliawati. (2019). Analisis pendapatan usahatani dan faktor-Faktor yang mempengaruhi risiko produksi bunga potong krisan di Desa Duren Kecamatan Bandungan. Agrikan: Jurnal Agribisnis Perikanan, 12 (1), 1-7. https://doi.org/10.29239/j.agrikan.12. 


\section{$1.1-7$}

Dwiratna, S., Suryadi, E., \& Kamaratih, K. (2016). Optimasi pola tanam pada lahan sawah tadah hujan di Kecamatan Cimanggung Kabupaten Sumedang. Jurnal Teknotan, 10(1), 37-45. Retrieved from https://jurnal.unpad.ac. $\mathrm{id} /$ teknotan/article/view/8886

Edeh, H. O., Eboh, E. C., \& Mbam, B. N. (2011). Analysis of environmental risk factors affecting rice farming in Ebonyi State, Southeastern Nigeria. World Journal of Agricultural Sciences, 7(1), 100-103. Retrieved from https://scholar.google.co.id/ scholar?cites $=17696454616537482005 \&$ as_s $\mathrm{dt}=2005 \&$ sciodt $=0,5 \& \mathrm{hl}=\mathrm{id} \&$ authuser $=3$

Fadlilah, S. N., Ariadi, B. Y., \& Relawati, R. (2019). Analisis risiko produksi bunga krisan di Desa Sidomulyo Kota Batu. Agriecobis: Journal of Agricultural Socioeconomics and Business, 02(02), 95-107. https://doi.org/ 10.22219/agriecobis.vol2.no2.95-107

Fitri, S., \& Mardhiah, A. (2018). Analisis komparatif produksi usahatani padi sawah lahan irigasi dan lahan tadah hujan di Kecamatan Simeulu Cut Kabupaten Simeulue. Jurnal Agriflora, 2(2), 78-88. Retrieved from http://jurnal.abulyatama.ac.id/index.php/agrifl ora/article/view/140

Hayashi, K., Llorca, L., Rustini, S., Setyanto, P., \& Zaini, Z. (2018). Reducing vulnerability of rainfed agriculture through seasonal climate predictions: a case study on the rainfed rice production in Southeast Asia. Agricultural Systems, 162, 66-76. https://doi.org/10.1016/j.agsy.2018.01.007

Ibrahim, Supamri, \& Zainal. (2020). Analisis faktor-faktor yang mempengaruhi pendapatan peternak rakyat sapi potong di Kecamatan Lampasio Kabupaten Tolitoli Provinsi Sulawesi Tengah. JSEP (Jurnal Sosial Ekonomi Pertanian), 13(3), 307-315. https:// doi.org/10.19184/jsep.v13i3.18446

Islam, M. D. I., Rahman, A., Sarker, M. N. I., Sarker, M. S. R., \& Jianchao, L. (2021). Factors influencing rice farmers' risk attitudes and perceptions in Bangladesh amid environmental and climatic issues. Polish Journal of Environmental Studies, 30(1), 177187. https://doi.org/10.15244/pjoes/120365
Kasno, A., Rostaman, T., \& Setyorini, D. (2016). Peningkatan produktivitas lahan sawah tadah hujan dengan pemupukan hara $\mathrm{N}, \mathrm{P}$, dan $\mathrm{K}$ dan penggunaan padi varietas unggul. Jurnal Tanah dan Iklim, 40(2), 147-157. Retrieved from http://ejurnal. litbang.pertanian.go.id/index.php/jti/article/vi ew/5727

Kumar, A., Kumar, S., Dahiya, K., Kumar, S., \& Kumar, M. (2015). Productivity and economics of direct seeded rice (Oryza sativa L.). Journal of Applied and Natural Science, 7(1), 410-416. https://doi.org/10.31018/jans. v7i1.625

Kurniati, D. (2014). Analisis risiko produksi dan faktor-faktor yang mempengaruhinya pada usahatani jagung (Zea mays L.) di Kecamatan Mempawah hulu Kabupaten Landak. Jurnal Sosial Ekonomi Pertanian, 1(3), 60-68. https://doi.org/10.26418/j.sea.v1i3.4366

Lailiyah, N., Timisela, N. R., \& Kaplale, R. (2017). Analisis produksi padi sawah (Oryza sativa L) tadah hujan di Desa Lea Wai Kecamatan Seram Utara Timur Kobi. Agrilan : Jurnal Agribisnis Kepulauan, 5(2), 151-165. http://dx.doi.org/10.30598/agrilan.v5i2.179

Lucas, M. P., \& Pabuayon, I. M. (2011). Risk perceptions, attitudes, and influential factors of rainfed lowland rice farmers in Ilocos Norte, Philippines. Asian Journal of Agriculture and Development, 8(2), 61-77. http://dx.doi.org/ 10.22004/ag.econ.199327

Magfira, M., Noor, T. I., \& Hakim, L. (2020). Analisis perbandingan risiko usahatani padi sawah dan padi rawa (suatu kasus di Desa Sukanagara Kecamatan Lakbok Kabupaten Ciamis). Jurnal Ilmiah Mahasiswa Agroinfo Galuh, 7(1), 14-27. https://doi.org/10.25157/ jimag.v7i1.2551

Magfiroh, W., \& Sofia. (2020). Strategi nafkah istri nelayan buruh di Desa Pengambengan Kecamatan Negara Kabupaten Jembrana. JSEP (Jurnal Sosial Ekonomi Pertanian), 13(1), 73-91. https://doi.org/10.19184/jsep. v13i1.16424

Mardliyah, A., \& Mirayana, E. (2019). Analisis resiko produksi dan pendapatan usahatani padi organik di Kecamatan Seputih Raman Kabupaten Lampung Tengah. Jurnal Wacana 
Pertanian, 15(1), 37-42. Retrieved from http://ojs.stiperdharmawacana.ac.id/index.php /jwp/article/view/49

Mastrordianto, Suyatno, A., \& Maswadi. (2019). Evaluasi kelayakan usahatani beras merah (Oryza nivara) di Desa Manis Raya Kecamatan Sepauk Kabupaten Sintang. Jurnal Social Economic of Agriculture, 8(1), 39-50. http://dx.doi.org/10.26418/j.sea.v8i1. 34131

Mita, R., Darma, R., Rahmadanih, Salam, M., \& Amrullah, A. (2020). Analisis risiko produksi usahatani padi di Pesisir Danau Tempe. Jurnal Sosial Ekonomi Pertanian, 16(1), 61-70. https://doi.org/10.20956/jsep.v16i1.7700

Murdayanti, M., Ibrahim, J. T., \& Baro, I. (2021). Farmer empowerment strategies through organic vegetables development. SOCA: Jurnal Sosial Ekonomi Pertanian, 15(1), 108119. Retrieved from https://ojs.unud.ac.id/ index.php/soca/article/view/58882

Mutisari, R., \& Meitasari, D. (2019). Analisis risiko produksi usahatani bawang merah di Kota Batu. Jurnal Ekonomi Pertanian dan Agribisnis (JEPA), 3(3), 655-662. https://doi. org/10.21776/ub.jepa.2019.003.03.21

Novickyte, L. (2018). Income risk management in agriculture using financial support. European Journal of Sustainable Development, 7(4), 191-202. https://doi.org/10.14207/ejsd.2018. v7n4p191

Nurbudiati, K., \& Wulandari, E. (2020). The risk and strategies of potato production in Garut, Indonesia. Caraka Tani: Journal of Sustainable Agriculture, 35(2), 191-202. https://doi.org/10.20961/carakatani.v35i2.340 72

Rahmadiah, R., Tanjung, F., \& Hariance, R. (2020). Analisis perbandingan usahatani padi sawah irigasi dengan padi sawah tadah hujan di Kecamatan Koto Tangah Kota Padang. JOSETA: Journal of Socio-Economics on Tropical Agriculture, 1(3), 9-23. https:// doi.org/10.25077/joseta.v1i3.177

Reda, A. G., Triphati, N. K., Soni, P., \& Tipdecho, T. (2015). Rain fed rice agriculture under climate variability in Southeast Asia: the case of Thailand. Journal of Earth Science \& Climatic Change, 6(8), 1-9. https://doi.org/

\section{$10.4172 / 2157-7617.1000297$}

Rondhi, M., Murti, J., Aji, M., \& Khasan, A. F. (2020). Risk aversion, risk preference and farmers' decision to participate in broiler contract farming: a case study in Jember, Indonesia. Caraka Tani: Journal of Sustainable Agriculture, 35(1), 98-107. https://doi.org/10.20961/carakatani.v35i1.379 64

Roy, R., \& Chan, N. W. (2015). Determinants of sustainable irrigated and rainfed rice farming in Bangladesh. Journal of Agricultural Science and Technology, 17(6), 1421-1435. Retrieved from https://www. researchgate.net/publication/284898000_Dete rminants_of_Sustainable_Irrigated_and_Rainf ed_Rice_Farming_in_Bangladesh

Safitri, N., Istiqomah, Widayaningsih, N., \& Purnomo, S. D. (2020). Analisis keanggotaan petani dalam kelompok tani: studi kasus kelompok pembudidaya ikan "Ulam Sari" Desa Kalikidang, Sokaraja, Banyumas. JSEP (Jurnal Sosial Ekonomi Pertanian), 13(1), 6572. https://doi.org/10.19184/jsep.v13i1.14821

Saleem, A., Muhammad, I., \& Ghazanfar, A. K. (2013). Decisive analysis of risks in agriculture: implications for agricultural extension for sustainable management. Spanish Journal of Rural Development, 4(3), 41-52. Retrieved from https://www. academia.edu/5671132/Decisive_analysis_of _risks_in_agriculture_implications_for_agric ultural_extension_for_sustainable_manageme $\mathrm{nt}$

Singh, K., Mcclean, C. J., Büker, P., Hartley, S. E., \& Hill, J. K. (2017). Mapping regional risks from climate change for rainfed rice cultivation in India. Journal Agriculture System, 156, 76-84. https://doi.org/10.1016/ j.agsy.2017.05.009

Suharyanto, S., Rinaldy, J., \& Arya, N. N. (2015). Analisis risiko produksi usahatani padi sawah di Provinsi Bali. AGRARIS: Journal of Agribusiness and Rural Development Research, 1(2), 70-77. https:// doi.org/10.18196/agr.1210

Sulaiman, A. A., Candradijaya, A., \& Syakir, M. (2019). Technological advancement and the economic benefit of Indonesian 
rain-fed farming development. Advances in Agriculture, 2019, 1-8. https://doi.org/ $10.1155 / 2019 / 9689037$

Sulewski, P., \& Gajewska, A. K. (2014). Farmers' risk perception, risk aversion and strategies to cope with production risk: an empirical study from Poland. Studies in Agricultural Economics, 116, 140-147. http://dx.doi.org/ 10.22004/ag.econ.196907

Wadu, J., Yuliawati, \& Nuswantara, B. (2019). Strategi menghadapi risiko produksi padi sawah di Kabupaten Sumba Timur. Jurnal Ekonomi dan Bisnis, 22(2), 231-256. https:// doi.org/10.24914/jeb.v22i2.2342
Yartiwi, Romeida, A., \& Utama, S. P. (2018). Uji adaptasi varietas unggul baru padi sawah untuk optimasi lahan tadah hujan berwawasan lingkungan di Kabupaten Seluma Provinsi Bengkulu. NATURALIS: Jurnal Penelitian Pengelolaan Sumberdaya Alam dan Lingkungan, 7(2), 91-97. https:// doi.org/10.31186/naturalis.7.2.6027

Zakirin, Yurisinthae, E., \& Kusrini, N. (2013). Analisis risiko usahatani padi pada lahan pasang surut di Kabupaten Pontianak. Jurnal Social Economic of Agriculture, 2(1), 75-84. http://dx.doi.org/ $10.26418 /$ j.sea.v2i1.5122 